\title{
Comparing Extraction and Quantity/Intensity Based Recommendations for Nitrogen, Phosphorus and Potassium Recommendation
}

\author{
Nqaba Nongqwenga ${ }^{1} \&$ Albert Thembinkosi Modi ${ }^{1}$ \\ ${ }^{1}$ Crop Science, School of Agricultural, Earth and Environmental Sciences, University of KwaZulu-Natal, \\ Scottsville, Pietermaritzburg, South Africa \\ Correspondence: Nqaba Nongqwenga, Crop Science, School of Agricultural, Earth and Environmental Sciences, \\ University of KwaZulu-Natal, Private Bag X01, Scottsville 3209, Pietermaritzburg, South Africa. Tel: \\ 27-33-260-5416. E-mail: nongqwenga3@gmail.com
}

\author{
Received: August 27, 2015 Accepted: November 2, 2015 Online Published: November 15, 2015 \\ doi:10.5539/jas.v7n12p220 URL: http://dx.doi.org/10.5539/jas.v7n12p220
}

\begin{abstract}
Conventional, extraction based fertilizer recommendations for phosphorus and potassium have been shown to lack mechanistic basis, thus unreliable. This has led to an urgent need for the development and evaluation of accurate and consistent phosphorus and potassium recommendations approaches with mechanistic basis. Also it has been shown that integrating nitrogen mineralization on nitrogen recommendations, has a potential of improving nitrogen recommendations. We established two parallel pot trial studies with the objective of comparing between extraction based fertilizer recommendations with alternative strategies. The first study was to compare the effect of integrating nitrogen mineralization on $\mathrm{N}$ recommendations. Second pot experiment in addition to $\mathrm{N}$ being recommended after integrating $\mathrm{N}$ mineralization; $\mathrm{P}$ and $\mathrm{K}$ were also recommended with an alternative strategy, which was derived from quantity/intensity relations. No negative impacts were observed on crop growth and nutrient uptake due to the integration of mineralizable nitrogen, despite nitrogen amounts being lower compared to treatments where $\mathrm{N}$ was applied without adjusting for mineralizable $\mathrm{N}$. The same was true for the second pot trial, $\mathrm{P}$ and $\mathrm{N}$ recommended by conventional approach were higher, yet the crop response was not concurrently improved by higher rates. Potassium rates recommended by alternative strategy were higher and this was concurrent with potassium uptake. We therefore concluded, that this NPK recommendation experimental approach $\left(\mathrm{N}_{\mathrm{e}} \mathrm{P}_{\mathrm{e}} \mathrm{K}_{\mathrm{e}}\right)$ is superior to its conventional counterpart $\left(\mathrm{N}_{\mathrm{c}} \mathrm{P}_{\mathrm{c}} \mathrm{K}_{\mathrm{c}}\right)$. Hence, more reliable recommendations can be developed using this approach and this might reduce environmental footprint of agro-ecosystems, and reduce input cost for farmers where warranted.
\end{abstract}

Keywords: nitrogen mineralization, fertilizer recommendations, quantity/intensity

\section{Introduction}

The use of extractions to index and calibrate phosphorus and potassium plant requirement as currently done is characterized by inaccuracies, lack of repeatability, specificity and inconsistences (Cox, 1994; Eckert, 1994; Jordan-Meille et al., 2012; Sharpley, 1994). Such attributes do not appear to be inherent errors between soil-plant relations rather soil-nutrient interactions which are poorly presented by the extractable or exchangeable phosphorus and potassium respectively as currently termed. Despite the differences with the choice of extractant or "philosophy" of recommendations there are not much differences within the approaches of extraction based recommendations. It appears that the only attractive feature of the approach lies in its simplicity and low cost, beyond which no justifications can be made for its appropriateness.

Soils by nature have varying affinities for ions, also ions interact with each other in ways which ultimately changes the availability of a particular ion for plant uptake in final soil solution; such are but of many dynamics which cannot be sufficiently accounted for by extraction based approaches. Works on potassium demonstrated that $\mathrm{K}$ dynamics are determined among many factors by activity ratio of $\mathrm{K}$ to other counter cations in soil solution, also by potassium potential, which is determined by soil physicochemical properties and management factors (Becket, 1971; Sparks, 1987; Sparks et al., 1990). From such studies it can be expected that calibrating fertilizer recommendations on the basis of such mechanisms would emerge as it is theoretically more 
mechanistic, however the reverse is true. Similarly, phosphorus levels in soil solution have been demonstrated that they can be more comprehensively presented by use of P sorption isotherms (Fox \& Kamprath, 1970; Chintala et al., 2014a), however these approaches have not gain the popularity one would expect, one of the major reason for this sluggish adoption of these concepts is mainly believed to be their laborious nature, hence highly expensive to be adopted as routine methods.

Nitrogen recommendations are also consider inefficient as such about $70 \%$ of applied $\mathrm{N}$ is lost (Raun \& Johnson, 1999; Chintala et al., 2012), although partially the inefficiency can be attributed to plant-N relations rather soil-plant relations. Rice and Havlin (1994) have suggested that subtracting mineralizable nitrogen from recommended nitrogen can improve inefficiencies. Mineralizable nitrogen has been shown to correlates well with $\mathrm{N}$ uptake under field conditions (Fox \& Piekielek, 1984). It is thus worth an effort to evaluate this index further.

There are several challenges associated with unsound fertilizer recommendations, such as over fertilization which might lead to unnecessary economic losses and negative environmental impacts, also under applying which might affect the final yield. Over applying one nutrient in respect to the other might also compromise other nutrients, through antagonistic reactions in either soil or plant.

The objective of a current study is to compare the response of plant growth and nutrient uptake under two different fertilizer recommendations approaches, i.e., conventional extraction approach and $\mathrm{Q} / \mathrm{I}$ relations. The impact of subtracting mineralizable $\mathrm{N}$ from $\mathrm{N}$ recommendations is also a subject of interest in this study.

\section{Materials and Methods}

The soil used for this pot trial was locally classified as Cartref soil form, according to the world reference base for soil resource it can be classified as Leptosol (Fey, 2010). The experiment was conducted at the University of KwaZulu-Natal, Pietermaritzburg Campus $\left(29^{\circ} 36^{\prime} \mathrm{S}, 30^{\circ} 23^{\prime} \mathrm{E}\right)$ under glasshouse conditions with maximum and minimum temperatures of $26^{\circ} \mathrm{C}$ and $16^{\circ} \mathrm{C}$, respectively.

\subsection{Fertilizer Recommendations}

Nitrogen mineralization potential of soil was determined by anaerobic incubations as suggested by (Waring \& Bremmer, 1964). This value was integrated by subtracting it from the amount of $\mathrm{N}$ recommended by conventional method (Rice \& Havlin, 1994). Net mineralizable $\mathrm{N}$ was calculated by Equation 1 to be $20 \mathrm{mg} \mathrm{kg}^{-1}$ of soil, and this value was subtracted from the initial recommendations made by conventional method and the actual amounts applied are given on Table 1.

$$
N_{\min }=N_{0}\left(1-e^{k t}\right)
$$

Where, $K$ is a mineralization rate constant taken to be 0.054 week $^{-1}$ (Stanford \& Smith, 1972); $N_{o}$ is a potentially mineralizable $N$; t is time; $N_{\min }$ is net mineralized $N$.

$\mathrm{Q} / \mathrm{I}$ based recommendations were based on sorption isotherms. These were developed by the batch equilibration technique as described by Fox and Kamprath (1970) and Beckett (1964) for P and K respectively. External P requirements $\left(\mathrm{mg} \mathrm{kg}^{-1}\right)$ were calculated based on Langmuir linearized equation targeting equilibrium concentration of $0.05 \mathrm{mg} \mathrm{L}^{-1}$ and $0.18 \mathrm{mg} \mathrm{L}^{-1}$ for maize and potato respectively, as these are assumed to be levels not limiting for respective crops. Both these critical equilibrium concentration levels were taken from Hue and Fox (2010). The K recommendations were applied to target intensity parameter of $0.02 \mathrm{~mol} / \mathrm{L}^{0.5}$ as suggested by Beckett (1964).

For extraction based approach; P was extracted by ammonium bicarbonate - EDTA solution (locally known as AMBIC). Applications are based on the difference between target and soil test $\mathrm{P}$ value multiplied by a purport buffer capacity value relating application rates with soil test, a parameter which is locally known as phosphorus requirements factor (PRF). The PRF's for individual soils are calculated using Equation 2.

$$
P R F=31.37 \times(\text { "sample density" })^{2}-94.13 \times \text { “sample density" }+73.5
$$

Where, sample density is mass/volume of soil sample passed through $2 \mathrm{~mm}$ sieved and expressed in $\left(\mathrm{g} \mathrm{ml}^{-1}\right)$, and $P R F$ is in $\mathrm{kg} \mathrm{ha}^{-1} / \mathrm{mg} \mathrm{L}^{-1}$. So that it can be interpreted as the amount of fertilizer per area of land required to raise soil test by $1 \mathrm{mg} \mathrm{L}^{-1}$, for further reading see Johnston et al. (1991). Similar approach is adopted for recommending $\mathrm{K}$, except that a value of 2.5 is inductively applied to relate the amount of fertilizer required to raise soil test by one unit. The actual quantities of fertilizer applied are given in Table 1. 
Table 1. quantities of fertilizer recommended by experimental approach and conventional approach for maize and potato

\begin{tabular}{llll}
\hline Nutrient and method & Abbreviation in the text & $\begin{array}{l}\text { Amount applied for maize } \\
\left(\mathrm{mg} \mathrm{kg}^{-1}\right)\end{array}$ & $\begin{array}{l}\text { Amount applied for potato } \\
\left(\mathrm{mg} \mathrm{kg}^{-1}\right)\end{array}$ \\
\hline N-conventional & $\mathrm{N}_{\mathrm{c}}$ & 45 & 75 \\
N-experimental & $\mathrm{N}_{\mathrm{e}}$ & 35 & 60 \\
P-conventional & $\mathrm{P}_{\mathrm{c}}$ & 65 & 100 \\
P-experimental & $\mathrm{P}_{\mathrm{e}}$ & 35 & 75 \\
K-conventional & $\mathrm{K}_{\mathrm{c}}$ & 300 & 650 \\
K-experimental & $\mathrm{K}_{\mathrm{e}}$ & 500 & 1000 \\
\hline
\end{tabular}

\subsection{Treatment Structure}

This section is consist of two parallel pot trials i.e., $\mathrm{N}$ based experiments when other nutrients are held at optimum constant levels. These are presented as $\mathrm{N}_{\mathrm{e}}$ i.e., $\mathrm{N}$ is applied using experimental approach (integrating mineralizable $\mathrm{N}$ ) and $\mathrm{PK}$ are at optimum levels. This treatment is compared to $\mathrm{N}_{\mathrm{c}}$ i.e., $\mathrm{N}$ is applied using conventional approach similar to previous treatment $\mathrm{P}$ and $\mathrm{K}$ are at constant optimal levels. Control for this treatment is presented as $\mathrm{N}_{\mathrm{o}}$ i.e., $\mathrm{N}$ is not applied, however, $\mathrm{P}$ and $\mathrm{K}$ are applied and are constant at optimal levels. Amounts of $\mathrm{P}$ that were considered optimum were 75 and $125 \mathrm{mg} \mathrm{kg}^{-1}$ for maize and potato respectively. Potassium amounts that were considered optimum were 325 and $675 \mathrm{mg} \mathrm{kg}^{-1}$ for maize and potato respectively.

The second pot trial was conducted to compare between the complete NPK fertilizer strategies. The conventional treatment is presented as $\mathrm{N}_{\mathrm{c}} \mathrm{P}_{\mathrm{c}} \mathrm{Kc}$ i.e., $\mathrm{N}, \mathrm{P}$ and $\mathrm{K}$ are applied using conventional method and abbreviated with $\left(\mathrm{N}_{\mathrm{c}} \mathrm{P}_{\mathrm{c}} \mathrm{K}_{\mathrm{c}}\right)$. This is compared to $\mathrm{N}_{\mathrm{e}} \mathrm{P}_{\mathrm{e}} \mathrm{K}_{\mathrm{e}}$ i.e., $\mathrm{N}, \mathrm{P}$ and $\mathrm{K}$ are applied using experimental approach whereby $\mathrm{P}$ and $\mathrm{K}$ are applied using $\mathrm{Q} / \mathrm{I}$ relations and $\mathrm{N}$ experimental is applied as outlined above. Control for this experiment is $\mathrm{N}_{\mathrm{o}} \mathrm{P}_{\mathrm{o}} \mathrm{K}_{\mathrm{o}}$ thus no fertilizer was applied on this treatment.

\subsection{Pot Trial Planting and Data Collection}

Maize cultivar EST: 1902 (border row king), and certified Mnandi cultivar potato seeds were planted on $2 \mathrm{~kg}$ soil. Three seeds of maize were planted initially on the $3^{\text {rd }}$ of November 2014, after 5 weeks (December 8, 2014) the first 2 plants were harvested $1 \mathrm{~cm}$ above the ground, and one plant was left behind. On the $8^{\text {th }}$ week (December $31,2014)$ the remaining plant was harvested $1 \mathrm{~cm}$ above ground. For potato one seed was planted per pot and the trial was harvested on the $8^{\text {th }}$ week $1 \mathrm{~cm}$ above ground, the trial was replicated three times. The pots were irrigated every second day after weighing to field capacity which was determined at $-33 \mathrm{kPa}$ suction pressure.

Plant height was measured using 1 meter long tape measure, chlorophyll content was measured using spud meter ( 3 readings were averaged for each plant). The plants were kept for 48 hours in $70{ }^{\circ} \mathrm{C}$ and thereafter biomass was determined.

\subsection{Plant Analysis and Statistical Analysis}

Same plant material used for biomass determination was grounded on ball miller. Later it was digested in the CEM microwave digester MARS 6 (CEM Corporation) using concentrated nitric acid. After digestion was complete, samples were prepared for analysis for $\mathrm{K}$ by AAS, and $\mathrm{P}$ was analyzed in an UV spectrometer using method of Murphy and Riley (1962). Total nitrogen and total carbon was measured using LECO CNS analyzer. Nutrient uptake was taken as an amount of nutrient multiplied by biomass.

Statistical analysis was performed using Genstat statistical software (Version 12.1, 2009). One way analysis of variance (ANOVA) was conducted by running a full model across treatments. Mean separation was done using the least significant difference (LSD) at $\mathrm{p}=0.05$. Ten more soils were analyzed so as to evaluate certain correlations.

\section{Results}

Physicochemical properties of the soil were typical for a sandy soil, as characterized by low clay content, and low buffering capacities for both $\mathrm{P}$ and $\mathrm{K}$ (Table 2). 
Table 2. Selected properties of the soils used for pot trials

\begin{tabular}{|c|c|}
\hline Parameters & \\
\hline $\mathrm{pH}(\mathrm{KCl})$ & 4.80 \\
\hline clay $(\%)$ & 8.00 \\
\hline AMBIC extractable $\mathrm{P}\left(\mathrm{mg} \mathrm{L}^{-1}\right)$ & 5.00 \\
\hline $\mathrm{NH}_{4} \mathrm{OAc}$ exchangeable $\mathrm{K}\left(\mathrm{mg} \mathrm{L}^{-1}\right)$ & 48.23 \\
\hline Phosphorus buffer capacity $(\mathrm{Q} / \mathrm{I}$ derived $)\left(\mathrm{mg} \mathrm{kg}-1 / \mathrm{mg} \mathrm{L}^{-1}\right)$ & 31.54 \\
\hline Potassium buffer capacity $(\mathrm{Q} / \mathrm{I}$ derived $)\left(\mathrm{mmol} \mathrm{kg}^{-1} / \mathrm{mmol} \mathrm{L}^{-1}\right)$ & 11.86 \\
\hline Equilibrium $\mathrm{P}(\mathrm{Q} / \mathrm{I}$ derived $)\left(\mathrm{mg} \mathrm{L}^{-1}\right)$ & 0.00521 \\
\hline Potassium activity ratio $(\mathrm{Q} / \mathrm{I}$ derived $)\left(\text { moles } \mathrm{L}^{-1}\right)^{0.5}$ & 0.000352 \\
\hline
\end{tabular}

It is worth noting in this instance that equilibrium $\mathrm{P}\left(\mathrm{mg} \mathrm{L}^{-1}\right)\left(\mathrm{Q} / \mathrm{I}\right.$ derived) and AMBIC extractable $\mathrm{P}\left(\mathrm{mg} \mathrm{L}^{-1}\right)$ (Extraction based) parameters represent the same factor (intensity parameter) and they are indices which inform about the bioavailable $\mathrm{P}$. For $\mathrm{K}$, the intensity factor is presented by $\mathrm{NH}_{4} \mathrm{OAc}$ exchangeable $\mathrm{K}$ and potassium activity ratio (ARo) for extraction and Q/I relations respectively. Buffer coefficients are parameters which inform about the rate of change of the intensity with the amount of fertilizer applied. It is worth noting that for extraction based approach this value for $\mathrm{K}$ recommendation it is assumed to be 2.5 in all soils, and for $\mathrm{P}$ it is calculated using (Equation 2).

\subsection{Effect of Integrating Nitrogen Mineralization on Crop Response}

Nitrogen fertilizer had a significant impact on most of the growth parameters measured (Table 3). Chlorophyll content index on maize of both conventional applied $\mathrm{N}\left(\mathrm{N}_{\mathrm{c}}\right)$ and $\mathrm{N}$ applied after adjusting for potential mineralizable $\mathrm{N}\left(\mathrm{N}_{\mathrm{e}}\right)$ were significantly higher than treatment where no $\mathrm{N}$ was applied $\left(\mathrm{N}_{\mathrm{o}}\right)$ at $\mathrm{p}=0.05$ (Table 3). $\mathrm{N}_{\mathrm{e}}$ and $\mathrm{N}_{\mathrm{c}}$ were not significantly different from each other with means almost equal in maize after 8 weeks of planting. Potato CCI values were highly significantly impacted by integrating Nm with $\mathrm{p}<0.001$. Integrating $\mathrm{N}$ mineralization index in potato resulted in significant improvement on CCI values compared to applying $\mathrm{N}$ using conventional methods; it is worth noting that when $\mathrm{N}$ was applied using conventional methods on potato there was no significant difference between $\mathrm{N}_{\mathrm{o}}$ and $\mathrm{N}_{\mathrm{c}}$ (Table 3).

The amount of $\mathrm{N}$ uptake by potato was not significantly impacted by integrating $\mathrm{N}$ mineralization on $\mathrm{N}$ recommendations (Table 4); the means between the two fertilizer recommendations strategies were almost equal, with value of 34.59 and $35.57 \mathrm{mg} \mathrm{pot}^{-1}$ (Table 4) for $\mathrm{N}_{\mathrm{e}}$ and $\mathrm{N}_{\mathrm{c}}$ respectively. The same was true for maize harvested after 8 weeks between $\mathrm{N}_{\mathrm{e}}$ and $\mathrm{N}_{\mathrm{c}}$. Contrary to potatoes; maize harvested after 8 weeks both $\mathrm{N}$ application strategies, significantly improved $\mathrm{N}$ uptake by maize, as characterized by significantly higher means compared to the control. Nonetheless, the maize harvested after 5 weeks $\mathrm{N}$ uptake was significantly higher on $\mathrm{N}_{\mathrm{c}}$ than $\mathrm{N}_{\mathrm{e}}$, and $\mathrm{N}$ uptake by $\mathrm{N}_{\mathrm{e}}$ fertilization strategy was significantly higher than $\mathrm{N}_{\mathrm{o}}$ (Table 4) at $\mathrm{p}=0.05$. The $\mathrm{P}$ uptake was only significantly impacted on maize harvested after 8 weeks. With both $\mathrm{N}_{\mathrm{e}}$ and $\mathrm{N}_{\mathrm{o}}$ significantly higher than $\mathrm{N}_{\mathrm{c}}$ (Table 4). Similar trends were observed on potato whereby $\mathrm{N}_{\mathrm{o}}$ was significantly higher than $\mathrm{N}_{\mathrm{c}}$, and not statistically different from $\mathrm{N}_{\mathrm{e}}$ at $\mathrm{p}=0.05$. Potassium uptake as affected by $\mathrm{N}$ recommendation strategy was only significantly affected on Potatoes, where $N_{e}$ was significantly higher than $N_{c}$ and $N_{c}$ was not statistically significant from $\mathrm{K}$ uptake of control pots. Total carbon content of plant material was significantly affected on maize harvested after 5 weeks, with control pots having a higher total $\mathrm{C}$ content than $\mathrm{N}$ treated pots, and $\mathrm{N}$ treated pots had means which were almost equal of 37.8 and 37.9 for $\mathrm{Ne}$ and $\mathrm{Nc}$ respectively (Table 4 ). 
Table 3. The Effect of integrating nitrogen mineralization index on maize and potato growth parameters

\begin{tabular}{|c|c|c|c|c|c|}
\hline \multirow{2}{*}{ Crops Treatment } & \multicolumn{3}{|c|}{ Fertilization strategy } & \multicolumn{2}{|c|}{ Statistical parameters } \\
\hline & $\mathrm{N}_{\mathrm{e}}^{\dagger}$ & $\mathrm{N}_{\mathrm{o}}+$ & $\mathrm{N}_{\mathrm{c}} \S$ & $\mathrm{LSD}_{\mathrm{p}=0.05}$ & Contrast \\
\hline & $C C I$ & & & & \\
\hline Maize $1 \dagger \dagger$ & 26.7 & 20.4 & 27.7 & 8.54 & $\mathrm{~ns}$ \\
\hline Maize $2+t$ & 19.63 & 12.1 & 19.7 & 4.44 & $* *$ \\
\hline \multirow[t]{2}{*}{ Potato } & 38.1 & 23.1 & 26.3 & 4.53 & $* *$ \\
\hline & Bioma & & & & \\
\hline Maize $1 \dagger \dagger$ & 7.877 & 7.817 & 8.473 & 0.44 & $*$ \\
\hline Maize $2+t$ & 12.47 & 10.83 & 11.25 & 0.815 & $* *$ \\
\hline \multirow[t]{2}{*}{ Potato } & 12.15 & 11.7 & 12.35 & 0.58 & $\mathrm{~ns}$ \\
\hline & Height & & & & \\
\hline Maize $1 \dagger \dagger$ & 48.3 & 41 & 48.7 & 15 & $\mathrm{~ns}$ \\
\hline Maize $2 t t$ & 83.3 & 51 & 66.3 & 12.12 & $* *$ \\
\hline \multirow[t]{2}{*}{ Potato } & 50.5 & 37 & 46 & 7.93 & $*$ \\
\hline & Leaf $n$ & & & & \\
\hline Maize $2+t$ & 3.67 & 2.33 & 4 & 0.94 & $*$ \\
\hline Potato & 6.5 & 3.5 & 7 & 1.82 & $* *$ \\
\hline
\end{tabular}

Note. $\uparrow$ Nitrogen applied after adjusting for potentially mineralizable nitrogen; $\$$ No nitrogen applied, $\mathrm{P}$ and $\mathrm{K}$ were at optimum; § Nitrogen applied using conventional method thus no adjustments were made; $\dagger \dagger$ maize harvested after 5 weeks; ++ maize harvested after 8 weeks; ${ }^{\mathrm{P}}<0.05 ; * * \mathrm{P}<0.01$; ns i.e., not significant.

Table 4. Effect of integrating nitrogen mineralization index on uptake of primary macronutrients and carbon content

\begin{tabular}{|c|c|c|c|c|c|}
\hline \multirow{2}{*}{ Crops Treatment } & \multicolumn{3}{|c|}{ Fertilization strategy } & \multicolumn{2}{|c|}{ Statistical parameters } \\
\hline & $\mathrm{Ne}_{\mathrm{e}}^{\dagger}$ & $\mathrm{N}_{\mathrm{o}}+$ & $\mathrm{N}_{\mathrm{c}} \S$ & $\mathrm{LSD}_{\mathrm{p}=0.05}$ & Contrast \\
\hline & \multicolumn{5}{|c|}{ N uptake $\left(m g\right.$ pot $\left.^{-1}\right)$} \\
\hline Maize $1 \dagger \dagger$ & 11.08 & 10.87 & 14.69 & 0.54 & $* *$ \\
\hline Maize $2+t$ & 13.64 & 10.12 & 13.34 & 2.55 & $*$ \\
\hline \multirow[t]{2}{*}{ Potato } & 43.2 & 38.3 & 46.7 & 7.82 & ns \\
\hline & \multicolumn{5}{|c|}{ P uptake ( $m g$ pot $\left.t^{-1}\right)$} \\
\hline Maize $1 \dagger \dagger$ & 6.23 & 10 & 9.41 & 3.96 & ns \\
\hline Maize $2+t$ & 9.54 & 9.56 & 5.53 & 3.1 & $*$ \\
\hline \multirow[t]{2}{*}{ Potato } & 19.6 & 22.9 & 12.4 & 9.02 & ns \\
\hline & \multicolumn{5}{|c|}{ K uptake $\left(m g\right.$ pot $\left.^{-1}\right)$} \\
\hline Maize $1 \dagger \dagger$ & 31.7 & 35.3 & 36.3 & 16.3 & ns \\
\hline Maize $2+t$ & 53.4 & 37.7 & 41.6 & 25.92 & ns \\
\hline \multirow[t]{2}{*}{ Potato } & 72.8 & 66.7 & 41.6 & 13.93 & $*$ \\
\hline & \multicolumn{5}{|c|}{ Tissue carbon content (\%) } \\
\hline Maize $1 \dagger \dagger$ & 37.79 & 40.48 & 37.9 & 0.66 & $* *$ \\
\hline Maize $2+\dagger$ & 36.28 & 36.76 & 37.7 & 2.42 & ns \\
\hline Potato & 34.69 & 33.48 & 35.57 & 2.37 & ns \\
\hline
\end{tabular}

Note. $\uparrow$ Nitrogen applied after adjusting for potentially mineralizable nitrogen; $\$$ No nitrogen applied, $\mathrm{P}$ and $\mathrm{K}$ were at optimum; § Nitrogen applied using conventional method thus no adjustments were made; $\dagger \dagger$ maize harvested after 5 weeks; $+t$ maize harvested after 8 weeks. ;* $\mathrm{P}<0.05$; ** $\mathrm{P}<0.01$; ns i.e., not significant.

\subsection{Effect of NPK Fertilization Strategy on Crop Response}

Mechanistic nutrient recommendations must be based on all three essential nutrients i.e., N, P and K. Second part 
of this results section focuses on integrating mineralizable $\mathrm{N}$ and recommending $\mathrm{P}$ and $\mathrm{K}$ using $\mathrm{Q} / \mathrm{I}$ relations, to form a single composite of NPK (experimental model). $\mathrm{N}$ and $\mathrm{P}$ amounts Table 1 were lower on experimental recommendations compared to conventional recommendations, and $\mathrm{K}$ applied was higher on experimental recommendations treatments compared to conventional recommendations.

NPK fertilization strategy caused no significant impact on the most growth parameters of maize at $p=0.05$ (Table 5). Biomass of maize between $\mathrm{N}_{c} \mathrm{P}_{c} \mathrm{~K}_{c}$ and $\mathrm{N}_{\mathrm{e}} \mathrm{P}_{\mathrm{e}} \mathrm{K}_{\mathrm{e}}$ was not significantly different from each other and both were significantly higher than $\mathrm{N}_{0} \mathrm{P}_{0} \mathrm{~K}_{0}$. Most of the observed growth parameters were equal between $\mathrm{N}_{\mathrm{e}} \mathrm{P}_{\mathrm{e}} \mathrm{K}_{\mathrm{e}}$ and $\mathrm{N}_{c} \mathrm{P}_{c} \mathrm{~K}_{c}$ (Table 5). Plant height was the only exception, with $\mathrm{N}_{\mathrm{e}} \mathrm{P}_{\mathrm{e}} \mathrm{K}_{\mathrm{e}}$ treated maize taller than $\mathrm{N}_{\mathrm{c}} \mathrm{P}_{\mathrm{c}} \mathrm{K}_{\mathrm{c}}$. Similarly on potato, biomass was not statistically different between $\mathrm{N}_{c} \mathrm{P}_{c} \mathrm{~K}_{c}$ and $\mathrm{N}_{\mathrm{e}} \mathrm{P}_{\mathrm{e}} \mathrm{K}_{\mathrm{e}}$. Chlorophyll content index on potato treated with $\mathrm{N}_{\mathrm{e}} \mathrm{P}_{\mathrm{e}} \mathrm{K}_{\mathrm{e}}$ was higher than $\mathrm{N}_{\mathrm{c}} \mathrm{P}_{\mathrm{c}} \mathrm{K}_{\mathrm{c}}$; this observation was consistent with the observation made earlier on $\mathrm{N}_{\mathrm{e}}$ (Tables 3 and 4).

Table 5. Effect of NPK fertilization strategy on maize and potato physiological growth parameters

\begin{tabular}{|c|c|c|c|c|c|}
\hline \multirow{2}{*}{ Crops Treatment } & \multicolumn{3}{|c|}{ Fertilization strategy } & \multicolumn{2}{|c|}{ Statistical parameters } \\
\hline & $\mathrm{N}_{\mathrm{c}} \mathrm{P}_{\mathrm{c}} \mathrm{K}_{\mathrm{c}} \dagger$ & $\mathrm{Ne}_{\mathrm{e}} \mathrm{P}_{\mathrm{e}} \mathrm{K}_{\mathrm{e}} \dagger$ & $\mathrm{N}_{\mathrm{o}} \mathrm{P}_{\mathrm{o}} \mathrm{K}_{\mathrm{o}} \S$ & $\mathrm{LSD}_{\mathrm{p}=0.05}$ & Contrast \\
\hline & $C C I$ & & & & \\
\hline Maize $1 \dagger \dagger$ & 27.7 & 25.9 & 24.9 & 6.94 & ns \\
\hline Maize $2 t t$ & 19.7 & 19.4 & 14.7 & 7.91 & ns \\
\hline \multirow[t]{2}{*}{ Potato } & 38.1 & 45.5 & 35.9 & 13.93 & ns \\
\hline & Biomass & & & & \\
\hline Maize $1 \dagger \dagger$ & 8.473 & 8.193 & 7.773 & 0.29 & $* *$ \\
\hline Maize $2+t$ & 11.25 & 11.97 & 10.83 & 0.88 & $*$ \\
\hline \multirow[t]{2}{*}{ Potato } & 12.35 & 11.5 & 11.23 & 0.69 & $*$ \\
\hline & Height ( & & & & \\
\hline Maize $1 \dagger \dagger$ & 48.7 & 50.7 & 37.7 & 11.76 & ns \\
\hline Maize $2 t t$ & 66.3 & 74.7 & 53 & 7.26 & $* *$ \\
\hline \multirow[t]{2}{*}{ Potato } & 46 & 44.3 & 29.3 & 8.1 & $* *$ \\
\hline & Leaf Nun & & & & \\
\hline Potato & 7 & 5.33 & 3.67 & 1.88 & $*$ \\
\hline
\end{tabular}

Note. †phosphorus and potassium applied based on extraction based conventional approach using ammonium bicarbonate-EDTA and ammonium acetate respectively. Nitrogen applied based on conventional approach thus no accounting for potentially mineralizable $\mathrm{N} ; \ddagger$ Phosphorus and potassium applied based on quantity/intensity relations, and nitrogen applied after potentially mineralizable $\mathrm{N}$ was adjusted for; $\S$ no fertilizer was applied; $\dagger \dagger$ maize harvested after 5 weeks; + maize harvested after 8 weeks; ${ }^{*} \mathrm{P}<0.05$; ** $\mathrm{P}<0.01$; ns i.e., not significant.

There were few significant impacts that were observed on nutrient uptake as a result of NPK recommendation strategies with most $\mathrm{P}$ values $>0.05$ (Table 6). The only exception on this trend was maize $\mathrm{K}$ uptake which was significantly affected on both harvest dates. Also total carbon content of maize harvested after 5 weeks and potato was significantly affected (Table 6). The general trend observed with regards to total carbon in both maize harvested after 5 and 8 weeks also on potatoes, was that control pots had higher total carbon content followed by NPK applied using conventional approach, and on pots that NPK was applied after integrating for mineralizable nitrogen and PK recommended based on Q/I relations had the lowest total carbon content on their tissues in both maize and potatoes. 
Table 6. Effect of NPK fertilization strategy on uptake of primary macronutrients and C content of maize and potato

\begin{tabular}{|c|c|c|c|c|c|}
\hline \multirow{2}{*}{ Crops Treatment } & \multicolumn{3}{|c|}{ Fertilization strategy } & \multicolumn{2}{|c|}{ Statistical parameters } \\
\hline & $\mathrm{N}_{\mathrm{c}} \mathrm{P}_{\mathrm{c}} \mathrm{K}_{\mathrm{c}} \dagger$ & $\mathrm{N}_{\mathrm{e}} \mathrm{P}_{\mathrm{e}} \mathrm{K}_{\mathrm{e}}$ & $\mathrm{N}_{0} \mathrm{P}_{0} \mathrm{~K}_{0} \S$ & $\mathrm{LSD}_{\mathrm{p}=0.05}$ & Contrast \\
\hline & \multicolumn{5}{|c|}{ N uptake $\left(m g\right.$ pot $\left.^{-1}\right)$} \\
\hline Maize $1 \dagger \dagger$ & 14.69 & 14.94 & 11.8 & 5 & $\mathrm{~ns}$ \\
\hline Maize $2+t$ & 13.45 & 14.93 & 11.8 & 4.88 & $\mathrm{~ns}$ \\
\hline \multirow[t]{2}{*}{ Potato } & 40.7 & 46.5 & 32.9 & 11.35 & $\mathrm{~ns}$ \\
\hline & \multicolumn{5}{|c|}{ P uptake (mg pot $\left.{ }^{-1}\right)$} \\
\hline Maize $1 \dagger \dagger$ & 9.41 & 8.32 & 4.93 & 4.51 & $\mathrm{~ns}$ \\
\hline Maize $2+4$ & 5.55 & 6.19 & 3.98 & 3.58 & ns \\
\hline \multirow[t]{2}{*}{ Potato } & 12.4 & 14.4 & 12.5 & 11.5 & ns \\
\hline & \multicolumn{5}{|c|}{ K uptake $\left(m g ~ p o t^{-1}\right)$} \\
\hline Maize $1 \dagger \dagger$ & 36.3 & 43.7 & 17.7 & 17.93 & $*$ \\
\hline Maize $2+$ & 41.6 & 44 & 16.2 & 12.34 & $* *$ \\
\hline \multirow[t]{2}{*}{ Potato } & 41.6 & 59.6 & 32.3 & 31.16 & ns \\
\hline & \multicolumn{5}{|c|}{ Tissue carbon content (\%) } \\
\hline Maize $1 \dagger \dagger$ & 37.9 & 37.27 & 40.67 & 2 & $*$ \\
\hline Maize $2+t$ & 37.7 & 36.34 & 41.01 & 4.11 & $\mathrm{~ns}$ \\
\hline Potato & 35.57 & 33.86 & 40.13 & 4 & $*$ \\
\hline
\end{tabular}

Note. †phosphorus and potassium applied based on extraction based conventional approach using ammonium bicarbonate-EDTA and ammonium acetate respectively. Nitrogen applied based on conventional approach thus no accounting for potentially mineralizable $\mathrm{N} ; \ddagger$ Phosphorus and potassium applied based on quantity/intensity relations, and nitrogen applied after potentially mineralizable $\mathrm{N}$ was adjusted for; $\S$ no fertilizer was applied; $\dagger \dagger$ maize harvested after 5 weeks; +4 maize harvested after 8 weeks; ${ }^{*} \mathrm{P}<0.05 ; * * \mathrm{P}<0.01$; ns i.e., not significant.

Nitrogen uptake of maize harvested after 8 weeks showed trends which were similar to those observed on Table 4. With $\mathrm{N}_{\mathrm{e}}>\mathrm{N}_{\mathrm{c}}$, this instance $\mathrm{N}$ uptake by $\mathrm{N}_{\mathrm{e}} \mathrm{P}_{\mathrm{e}} \mathrm{K}_{\mathrm{e}}$ was greater than $\mathrm{N}_{\mathrm{c}} \mathrm{P}_{\mathrm{c}} \mathrm{K}_{\mathrm{c}}$.

\subsection{Selected Correlations between Total Carbon with Nutrients Content and Biomass}

Total carbon content of plant material is hardly reported on plant nutrition studies, however the trends in this instance were too persistent to ignore. From Table 6 both harvest times for maize we obtained significant results whereby total carbon was the significantly high $(\mathrm{P}<0.05)$ in control pots followed by $\mathrm{N}_{c} \mathrm{P}_{c} \mathrm{~K}_{c}$, and $\mathrm{N}_{\mathrm{e}} \mathrm{P}_{\mathrm{e}} \mathrm{K}_{\mathrm{e}}$ had the lowest total carbon content (Table 6).

When nutrient content of maize (P, K and S) was plotted against total carbon showed an appreciable inverse correlation (Figure 1). This ranged from 0.92 to 0.40 for maize harvested after 5 weeks and potato respectively. In all assessed correlation, potato nutrient contents showed the least agreement with total carbon. While maize nutrient contents harvested after 5 weeks showed the highest correlation. Similar inverse relation with total carbon was obtained for potato and maize harvested after 8 weeks with $r^{2}$ of 0.33 and 0.74 respectively (Figure 2). 

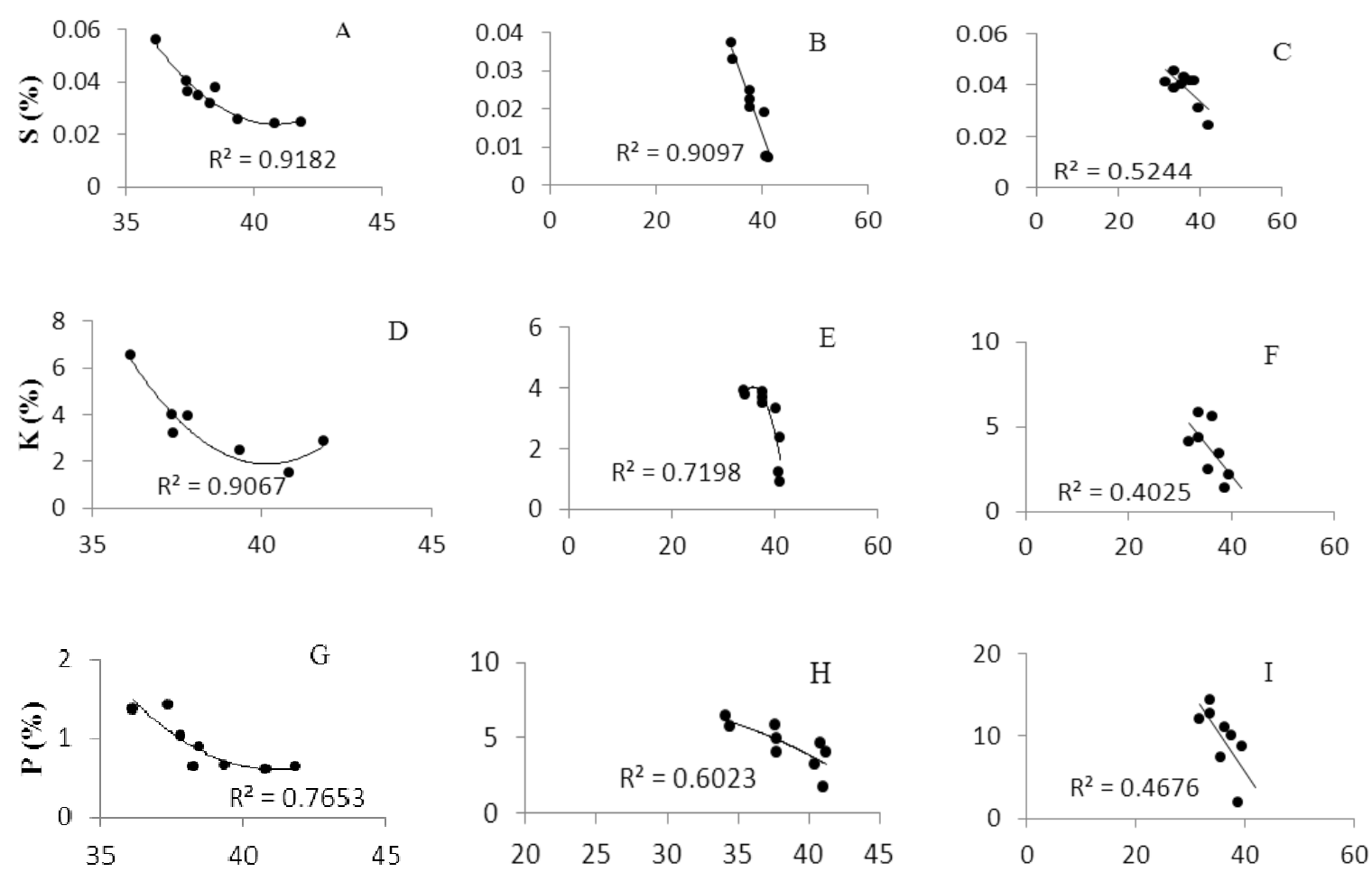

Figure 1. Correlation between total plant carbon with various nutrients, for A, D and G maize harvested after 5 weeks. For B, E, and H for maize harvested after 8 weeks. For C, F and I for potato harvested after 8 weeks.

With nutrients given on the $\mathrm{y}$-axis, where, $\mathrm{S}, \mathrm{P}$ and $\mathrm{K}$ refers to sulfur, phosphorus and potassium content respectively
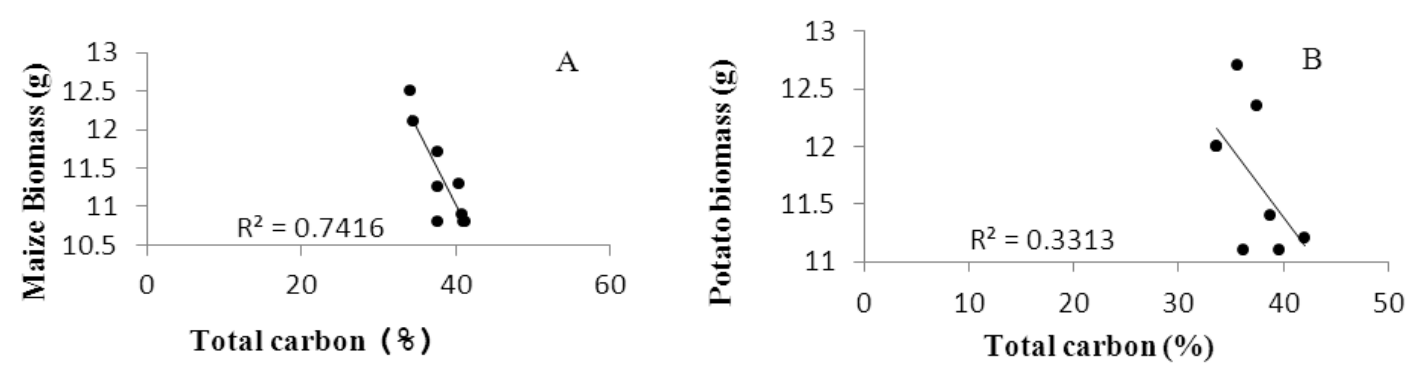

Figure 2. Correlation ship between total carbon with (A) maize biomass harvested after 8 weeks, (B) with potato biomass harvested after 8 weeks

\section{Discussion}

Higher values of CCI on N treated pots are consisted with the observation that were made by van den Berg and Perkins (2004) on sugar maple leaves. They observed a positive correlation between N content and CCI. There were no negative impacts which were observed on both maize and potato growth parameter as a result of subtracting mineralizable $\mathrm{N}$ from $\mathrm{N}$ recommendations (Table 3), as it would have been so if $\mathrm{N}$ applied was below sufficiency. This might be because of two reasons. 1) Subtracting mineralizable $\mathrm{N}$ did not impact the growth of maize or potato, because even after subtracting mineralizable $\mathrm{N}$ from the recommendations the amount of $\mathrm{N}$ applied was still sufficient to not negatively impact crop growth. 2) mineralizable $\mathrm{N}$ actually compensated for the amounts of $\mathrm{N}$ that were subtracted on its account from initial recommendations hence no differences observed on most of the growth parameters between $\mathrm{N}_{\mathrm{e}}$ and $\mathrm{N}_{\mathrm{c}}$.

To this end we propose that mineralizable $\mathrm{N}$ subtracted from the initial recommendations actually compensated for $\mathrm{N}$ subtracted on its account. We support this proposal by Table 3 using CCI, biomass and plant height of maize and CCI of potato. As we have observed that these parameters were lower in $\mathrm{N}_{\mathrm{e}}$ compared to $\mathrm{N}_{\mathrm{c}}$ on first harvest ( 5 weeks), and significantly so when we asses above ground biomass. This might be because of faster 
turnover of plant material (Gordon et al., 2000). This occurrence is characterized by accelerated turnover of biomass during earlier stage of establishment under high mineral $\mathrm{N}$ content. However, this is usually not sustained for longer periods. This is in support with observation made after 8 weeks when these parameters between $\mathrm{N}_{\mathrm{e}}$ and $\mathrm{N}_{\mathrm{c}}$ were not different in fact they were higher on $\mathrm{N}_{\mathrm{e}}$ treatments compared to $\mathrm{N}_{\mathrm{c}}$. One of the many possible mechanisms driving high turnover might be because $\mathrm{N}$ fertilizer is readily soluble hence immediately available, hence higher turnover during establishment phase. This is in contrary to mineralizable $\mathrm{N}$ which is slowly available.

It was however observed that despite this improved establishments, after 8 weeks of planting both maize and potato showed some unconventional response to $\mathrm{N}$ fertilization strategy. Characterized by an inverse relationship between growth parameters and amount of fertilizer applied, this phenomenon was evident between $\mathrm{N}_{\mathrm{e}}$ and $\mathrm{N}_{\mathrm{c}}$, since amount of $\mathrm{N}$ fertilizer on $\mathrm{N}_{\mathrm{c}}$ treatments was greater than the amount of $\mathrm{N}$ fertilizer applied on $\mathrm{N}_{\mathrm{e}}$. The inverse relationship was observed on the above ground biomass of maize harvested after 8 weeks which was significantly higher on $\mathrm{N}_{\mathrm{e}}$ treatment compared to $\mathrm{N}_{\mathrm{c}}$ (Table 3). This trend was further observed on plant height of both maize and potato, and $\mathrm{CCI}$ of potato. This trend was consistent with the uptake of $\mathrm{N}$ by maize harvested after 8 weeks (Table 4 ).

The inverse relationship between growth and $\mathrm{N}$ uptake might be due to the priming effect (increase in nitrogen mineralization rate constant), hence increase in mineralized $\mathrm{N}$ which is subjected to the plant uptake. This might also contribute to higher turnover during earlier stages of growth as earlier proposed. This proposition can explain the observed occurrence in a sense that $\mathrm{N}_{\mathrm{e}}$ received lower $\mathrm{N}$ fertilizer, subsequently priming effect was proportionally influenced relative to $\mathrm{N}_{\mathrm{c}}$ (Jenkinson et al., 2006). Implying that mineralizable pool (No) is reduced to levels which are still relatively higher than $\mathrm{N}_{\mathrm{c}}$ treatments, thus able to continuously and natively supply $\mathrm{N}$ in levels which are proportionally higher than $\mathrm{N}_{\mathrm{c}}$. The primed $\mathrm{N}$ is perhaps luxuriously consumed leading to initially higher turnover, then $\mathrm{N}$ uptake will steadily decline due to the reduction in $\mathrm{N}$ source, it is worth noting this is one of the justifications for split $\mathrm{N}$ application (Lopez-Bellido et al., 2005). Luxuriously consumed $\mathrm{N}$ does not concurrently improves growth on long term basis and associated parameters (Lipson et al., 1996). Luxuriously consumed $\mathrm{N}$ is also not metabolized into functional or structural components, nor does it lead to excess $\mathrm{N}$ uptake this is in agreement with observations made on $\mathrm{N}$ uptake of maize (Table 4). Luxury consumed $\mathrm{N}$ might be accumulated into nonstructural carbohydrates hence perhaps the reason for higher plant total carbon of $\mathrm{N}_{\mathrm{c}}$ treatments (Table 4). Also this might support earlier made proposition about potentially mineralizable compensating for $\mathrm{N}$ withheld on its account on this study.

Higher P uptake on controls compared to $\mathrm{N}_{\mathrm{c}}$ yet not statistically different from $\mathrm{N}_{\mathrm{e}}$ on Table 4 contradicts most studies which have been conducted on N-P relations on agro-ecosystems, which have demonstrated that $\mathrm{P}$ uptake is proportional to amount of $\mathrm{N}$ fertilizer applied (Coblent et al., 2004). Nonetheless, several studies which have conducted mainly on natural ecosystem have demonstrated negative correlation between $\mathrm{N}: \mathrm{P}$ ratio and $\mathrm{P}$ content (Gusewell, 2004) this concept have been linked with nitrogen saturation (Aber, 1992). Nitrogen to phosphorus ratio implies that at certain levels of $\mathrm{P}$ the plant response to $\mathrm{P}$ is independent of $\mathrm{P}$ concentration, rather it is determines by the ratio between $\mathrm{N}$ and $\mathrm{P}$. So that if $\mathrm{N}$ concentrations relative to $\mathrm{P}$ increases hence $\mathrm{N}: \mathrm{P}$ ratio, the $\mathrm{P}$ uptake is limited. Also potassium uptake of both maize and potato harvested after 8 weeks demonstrated similar patterns as $P$ uptake where $N_{e}>N_{c}$ it is worth noting that even $N_{o}$ on potato had higher $K$ uptake compared to conventionally applied $\mathrm{N}$ treatments.

Mechanistic nutrient recommendations must be based on all three essential nutrients i.e., N, P and K. Second part of this discussion focuses on integrating mineralizable $\mathrm{N}$ and recommending $\mathrm{P}$ and $\mathrm{K}$ using $\mathrm{Q} / \mathrm{I}$ relations, to form a single composite of NPK (experimental model). Growth parameters in this instance are subjective given that all three nutrients were variables, thus variances observed cannot be conclusively ascribed to a particular nutrient. Given that most of the parameters were equal especially for maize, this implies that both treatments were equally effective. Nonetheless, considering that $\mathrm{N}$ and $\mathrm{P}$ were higher under $\mathrm{N}_{\mathrm{c}} \mathrm{P}_{\mathrm{c}} \mathrm{K}_{\mathrm{c}}$ treatment, it can be inferred that higher applications recommended by conventional methods were unjustified, at similar rate higher $\mathrm{K}$ recommendations made by experimental approach were perhaps unwarranted. In order to assess the effectiveness of fertilization strategy we considered uptake of the individual nutrients given on Table 6. Nitrogen uptake of maize harvested after 8 weeks showed trends which were similar to those observed on Table 4 . With $\mathrm{N}_{\mathrm{e}}>\mathrm{N}_{\mathrm{c}}$, this instance $\mathrm{N}$ uptake by $\mathrm{N}_{\mathrm{e}} \mathrm{P}_{\mathrm{e}} \mathrm{K}_{\mathrm{e}}$ was greater than $\mathrm{N}_{\mathrm{c}} \mathrm{P}_{\mathrm{c}} \mathrm{K}_{\mathrm{c}}$, perhaps these observations support earlier made propositions, regarding priming effect of $\mathrm{N}$ fertilizer and its ultimate effect on long term basis.

Unconventional results were observed regarding $\mathrm{P}$ uptake, these were characterized by an average higher $\mathrm{P}$ uptake of both maize and potato when NPK recommendations were made by experimental compared to conventional approach. These results are in conflict with general fundamental relations considering that $\mathrm{N}_{\mathrm{c}} \mathrm{P}_{\mathrm{c}} \mathrm{K}_{\mathrm{c}}$ 
recommended higher $\mathrm{P}$ compared to $\mathrm{N}_{\mathrm{e}} \mathrm{P}_{\mathrm{e}} \mathrm{K}_{\mathrm{e}}$, but the reverse was true for the $\mathrm{P}$ uptake. We ascribed this observance to Gusewell (2004) proposition of N:P ratio. That the relative increase of N must concurrently increase with $\mathrm{P}$, the consequences of unbalanced ratios between $\mathrm{N}$ and $\mathrm{P}$ include reduced $\mathrm{P}$ uptake (Gusewell, 2004). This might be the case considering that $\mathrm{N}: \mathrm{P}$ ratio of $\mathrm{N}_{\mathrm{e}} \mathrm{P}_{\mathrm{e}} \mathrm{K}_{\mathrm{e}}$ treatment for maize was $1: 1$, while for $\mathrm{N}_{\mathrm{c}} \mathrm{P}_{\mathrm{c}} \mathrm{K}_{\mathrm{c}}$ was 3:5 (Table 6). The proposition is true for potatoes with $\mathrm{N}: \mathrm{P}$ under $\mathrm{N}_{\mathrm{e}} \mathrm{P}_{\mathrm{e}} \mathrm{K}_{\mathrm{e}}$ being $4: 5$ while for $\mathrm{N}_{\mathrm{c}} \mathrm{P}_{\mathrm{c}} \mathrm{K}_{\mathrm{c}}$ is $3: 4$.

Despite the possibilities of perturbed ratios, it is also apparent that higher $\mathrm{P}$ recommendations made by conventional approach were unnecessarily high, since $\mathrm{P}$ uptake was not improved under $\mathrm{N}_{\mathrm{c}} \mathrm{P}_{\mathrm{c}} \mathrm{K}_{\mathrm{c}}$. The artificially high $\mathrm{P}$ recommendation might be ascribed to the nature of extracting solution. $\mathrm{OH}^{-}$ions in an ammonium bicarbonate EDTA-NaF solution, can solubilize Fe and Al bound P (Kamprath \& Watson, 1980; Chintala et al., 2014b). Also carbonate $\left(\mathrm{HCO}_{3}\right)$ in the solution can replace adsorbed $\mathrm{P}$. This consequently makes the solution more ideal for highly weathered soils contrast to the sandy soil used for this experiment. Thus calibrating using this solution might cause artificially high soil test $\mathrm{P}$ values, based on non-universal $\mathrm{P}$ pools.

Despite lack of significance to $\mathrm{K}$ uptake results, there was a parallel increase in $\mathrm{K}$ uptake with higher $\mathrm{K}$ levels recommended by $\mathrm{N}_{\mathrm{e}} \mathrm{P}_{\mathrm{e}} \mathrm{K}_{\mathrm{e}}$, contrary to the inverse relations which were observed when $\mathrm{N}$ and $\mathrm{P}$ were recommended in higher quantities by $\mathrm{N}_{\mathrm{c}} \mathrm{P}_{\mathrm{c}} \mathrm{K}_{\mathrm{c}}$ approach. Potassium optimum levels for the conventional method are based on $\mathrm{NH}_{4} \mathrm{OAc}$ extractable $\mathrm{K}$ which reflects intensity parameter. For Q/I relations intensity parameter is derived from the activity ratio of $\mathrm{K} /(\mathrm{Ca}+\mathrm{Mg})$. Significance of the latter approach is based on the ternary exchange between $\mathrm{K}-\mathrm{Ca}-\mathrm{Mg}$ especially in agricultural soils where these ions are dominating soil matrix (Romheld \& Kirkby, 2010; Sparks et al., 1990). Ohno and Grunes (1985); Welte and Werner (1963); and Jakobsen (1992) conclusively demonstrated that either $\mathrm{K}, \mathrm{Ca}$ or $\mathrm{Mg}$ deficiencies are not exclusively dependent on the soil solution concentration. Interactions between the ions also play a crucial role, and this relationship is commonly antagonistic in nature, hence quantifying these ions by accounting for these interactions is mechanistically justified. Soil surface prefer divalent cations over monovalent cations, however this preference is not fixed, it is dynamic depending on the ratio of $\mathrm{K}: \mathrm{Ca}: \mathrm{Mg}$, or even $\mathrm{Na}$ in sodic soils and $\mathrm{Al}$ in acidic soils (Agbenin \& Yakubu, 2006; Chintala et al., 2013). The solution concentration is inversely correlated with the preference for a respective ion, so that when soils show higher preference for that particular ion its buffering capacity will be higher, and ultimately the effectiveness of fertilizer in increasing its concentration in solution will be lower. The preference is commonly indexed by Gapon, or Vanselow selectivity coefficients, and these are quantified by the same principle applied in this study to calculate KBC.

This is in contrast to the traditional extraction methods, which overlooks these relations. The lack of any form of buffer coefficient for $\mathrm{K}$ as currently applied in various soil testing institution compromise any possibility of accuracy in the method. On a technical standpoint it is only buffer coefficient which has a capability of quantifying the rate of change in solution concentration per amount of fertilizer applied. Not accounting for $\mathrm{K}$ buffer capacity is not only evident in South Africa, even similar axiomatic assumptions of standard values in relating external applications with solution concentration is evident in the United State; in Ohio States it has been reported by Vitosh et al. (1995), and in South Dakota it has been reported by Gerwing and Gelderman (2005).

We ascribed the inverse correlation between nutrients and total carbon observed in this study to a well-studied concept in ecological chemistry i.e., carbon/nutrient balance theory (CNB) (Bryant et al., 1983). According to the theory, fertilization reduces production of carbon based metabolites, with special reference to phenolics and terpenes. Although these metabolites were not measured in this study, previous studies that have been conducted by Cronin and Lodge (2003), Mohd et al. (2010) have demonstrated a positive correlation between these compounds with total carbon. Mohd et al. (2010) observed that $82 \%$ variation in the concentration of these compounds can be explain by total carbon. The CNB theory postulates about biomass production; stipulating that there is a negative correlation between carbon based compounds with biomass production. This claim is in accord with the correlation observed in Figure 2, given we accept the Mohd et al. (2010) correlations to hold true in this instance.

This theory provides a unifying insight with regards to the conduciveness of the nutrient environment as a whole rather as a particular nutrient. Similar to the conclusion reached by Bazzaz and Reekie (1987), that carbon allocation reflect the allocation of resources in particular those limiting resources (NPK). We hypothesize therefore that perhaps total carbon might provide that net effect due to the variables of the experiment. This net effect is reflective of optimality or lack thereof, of the treatments, based on optimal physiological response of crops to the fertilizer treatment strategies, as a whole rather for individual nutrients. So that if this supplementary rudimentary hypothesis is true, fertilization strategy as a whole should be assessed among other parameters on the basis of its effect on carbon content. Since carbon content on this study showed an inverse relation with biomass and nutrient content we further propose that fertilization strategy preeminence must be parallel with this 
drop on tissue carbon under non-carbon limiting environments. Although this is hypothesis it might hold true given previous ecological studies which have shown carbon content to be an important predictor of ecological productivity.

In addition to the previously observed support from crop response and nutrient uptake for the experimental fertilizer strategy proposed here, for both studies $\mathrm{N}_{\mathrm{e}}$ and $\mathrm{N}_{\mathrm{e}} \mathrm{P}_{\mathrm{e}} \mathrm{K}_{\mathrm{e}}$; we further propose that the aforementioned theory is in favor of the eminence of this strategy. There are 6 independent observations made on this study to assess both $\mathrm{N}_{\mathrm{e}}$ and $\mathrm{N}_{\mathrm{e}} \mathrm{P}_{\mathrm{e}} \mathrm{K}_{\mathrm{e}}$. The 2 separate observations were made on maize harvested after 5 weeks, under $\mathrm{N}_{\mathrm{e}}$ and $\mathrm{N}_{\mathrm{e}} \mathrm{P}_{\mathrm{e}} \mathrm{K}_{\mathrm{e}}$, the other 4 constitutes maize harvested after 8 weeks and potato harvested after 8 weeks, with similar treatment structure of $\mathrm{N}_{\mathrm{e}}$ and $\mathrm{N}_{\mathrm{e}} \mathrm{P}_{\mathrm{e}} \mathrm{K}_{\mathrm{e}}$ compared to $\mathrm{N}_{\mathrm{c}}$ and $\mathrm{N}_{\mathrm{c}} \mathrm{P}_{\mathrm{c}} \mathrm{K}_{\mathrm{c}}$. In all of the observation made total tissue $\mathrm{C}$ was lowest when fertilizer recommendations were made by the experimental approach presented here (Tables 4 and 6). The slight exception to this claim was observed on maize harvested after 5 weeks where tissue $\mathrm{C}$ was almost equal between $\mathrm{N}_{\mathrm{e}} \mathrm{P}_{\mathrm{e}} \mathrm{K}_{\mathrm{e}}$ and $\mathrm{N}_{\mathrm{c}} \mathrm{P}_{\mathrm{c}} \mathrm{K}_{\mathrm{c}}$ with values of $37.8 \%$ and $37.9 \%$ for $\mathrm{N}_{\mathrm{e}} \mathrm{P}_{\mathrm{e}} \mathrm{K}_{\mathrm{e}}$ and $\mathrm{N}_{\mathrm{c}} \mathrm{P}_{\mathrm{c}} \mathrm{K}_{\mathrm{c}}$ respectively (Table 6).

\section{Conclusions}

Subtracting mineralizable nitrogen from conventional nitrogen recommendations did not have negative impact on growth of maize and potato under glasshouse study, it showed positive effects as parameterized by reduced fertilizer rates, improved nutrient uptake and growth of both crops. If this is true under field conditions it has a potential of economic savings on nitrogen fertilizer. The Experimental approach employed in this study showed a potential, despite lower $\mathrm{N}$ and $\mathrm{P}$ rates the performance of both crops was not inferior compared to its conventional counterpart. The accuracy of extraction based fertilizer recommendations is highly unconvincing based on this study.

\section{References}

Aber, J. D. (1992). Nitrogen cycling and nitrogen saturation in temperate forest ecosystem. Trends in Ecology and Evolution, 7, 220-224. http://dx.doi.org/10.1016/0169-5347(92)90048-G

Agbenin, J. O., \& Yakubu, S. (2006). Potassium-calcium and potassium-magnesium exchange equilibria in an acid savanna soil from northen Nigeria. Geoderma, 136, 542-554. http://dx.doi.org/10.1016/j.geoderma.2006.04.008

Bazzaz, F. A., Reekie, E. G. (1987). Reproductive Effort in Plants. 2. Does carbon reflect the allocation of other resources? The American Naturalist, 129, 897-906. http://dx.doi.org/10.1086/284682

Becket, P. H. T. (1971). Potassium potential a review. Potash Review, Subject 5, Suite 30(1), 41.

Beckett, P. H. T. (1964). Studies on soil potassium II. The immediate Q/I relations of labile potassium in the soil. Journal of Soil Science, 15, 9-22. http://dx.doi.org/10.1111/j.1365-2389.1964.tb00240.x

Bryant, J., Chappin III, F., \& Klein, D. (1983). Carbon/nutrient balance of boreal plants in relation to vertebrate herbivory. Oikos, 40, 357-368. http://dx.doi.org/10.2307/3544308

Chintala, R., McDonald, L. M., \& Bryan, W. B. (2012). Effect of soil water and nutrients on productivity of Kentucky bluegrass systems in acidic soils. Journal of Plant Nutrition, 35, 288-303. http://dx.doi.org/10.1080/01904167.2012.636131

Chintala, R., Mollinedo, J., Schumacher, T. E., Malo, D. D., \& Julson, J. L. (2014b). Effect of biochars on chemical properties of acidic soil. Archives of Agronomy and Soil Science, 60(3), 393-404. http://dx.doi.org/10.1080/03650340.2013.789870

Chintala, R., Mollinedo, J., Schumacher, T. E., Malo, D. D., Papiernik, S., Clay, D. E., ... Gulbrandson, D. W. (2013). Nitrate sorption and desorption by biochars produced from microwave pyrolysis. Microporous and Mesoporous Materials, 179, 250-257. http://dx.doi.org/10.1016/j.micromeso.2013.05.023

Chintala, R., Schumacher, T. E., McDonald, L. M., Clay, D. E., Malo, D. D., Clay, S. A., ... Julson, J. L. (2014a). Phosphorus sorption and availability in biochars and soil biochar mixtures. CLEAN-Soil Air Water, 42(5), 626-634. http://dx.doi.org/10.1002/clen.201300089

Coblent, W. K., Daniels, M. B., Gunsaulis, J. L., Turner, J. E., Scarbhrough, D. A., Humphry, J. B., ... Speight, J. D. (2004). Effects of Nitrogen fertilization on phosphorus uptake in Bermudagrass forage grown on high soil test phosphorus sites. The Professional Animal Scientist, 20, 146-154.

Cox, F. R. (1994). Current Phosphorus Availability Indices: Characteristics and Shortcomings. Soil Testing: Prospects for Improving Nutrient Recommendations: Soil Science Society of America Special Publication, 
40, 101-113.

Cronin, G., \& Lodge, D. M. (2003). Effects of light and nutrient availability on the growth, allocation, carbon/nitrogen balance, phenolic chemistry, and resistance to herbivory of two freshwater macrophytes. Oecologia, 137, 32-41. http://dx.doi.org/10.1007/s00442-003-1315-3

Eckert, D. J. (1994). Site-Specific Soil Tests and Interpretations for Potassium Soil Science Society of America Special Publication, 40, 163-171.

Fey, M. (2010). Soils of South Africa. Cambridge University Press, Singapore. http://dx.doi.org/10.1017/CBO9780511782183

Fox, R. H., \& Piekielek, W. P. (1984). Relationships between among anaerobically mineralized nitrogen, chemical indexes and nitrogen availability to corn. Soil Science Society of America Journal, 48, 1087-1090. http://dx.doi.org/10.2136/sssaj1984.03615995004800050027x

Fox, R. L., \& Kamprath, E. J. (1970). Phosphate sorption isotherms for evaluating the phosphate requirements of soils. Soil SCience Society of America Proceedings, 34, 902-907. http://dx.doi.org/10.2136/sssaj1970.03615995003400060025x

Gerwing, J., \& Gelderman, R. H. (2005). South Dakota Fertilizer Recommendations Guide. USDA Cooperative Extension Services.

Gordon, C., Wynn, J. M., \& Woodin, S. J. (2000). Impacts of nitrogen supply on high Arctic heath: the importance of bryophytes and phosphorus availability. New Phytologist, 149, 461-471. http://dx.doi.org/10.1046/j.1469-8137.2001.00053.x

Gusewell, S. (2004). N:P ratios in terrstrial variation and functional significance. New Phytologist, 164, $243-266$. http://dx.doi.org/10.1111/j.1469-8137.2004.01192.x

Hue, N. V., \& Fox, R. L. (2010). Combination of phosphorus sorption isotherm and chemical extraction methods. Communications in Soil Science and Plant Analysis, 41, 133-134. http://dx.doi.org/10.1080/00103620903426949

Jakobsen, S. T. (1992). Interaction between plant nutrients: III. Antagonism between potassium, magnesium and calcium. Acta Agriculturae Scandinavica, Section B - Soil and Plant Science, 43, 1-5.

Jenkinson, D. S., Fox, R. H., \& Rayner, J. H. (2006). Interaction between fertilizer nitrogen and soil nitrogen-the soi called 'priming' effect. Journal of Soil Science, 36, 425-444. http://dx.doi.org/10.1111/j.1365-2389.1985.tb00348.x

Johnston, M. A., Miles, N., \& Thibaud, G. R. (1991). Quantities of phosphorus fertilizer required to raise the soil test value. South African Journal of Soil and Plants, 8, 17-21. http://dx.doi.org/10.1080/02571862.1991.10634573

Jordan-Meille, L., Rubaek, G. H., Ehlert, P. A. I., Genot, V., Hofman, G., Goulding, K., ... Barrachlough, P. (2012). An overview of fertilizer-P recommendations in Europe: soil testing, calibration and fertilizer recommendations. Soil Use and Management, $419-435$. http://dx.doi.org/10.1111/j.1475-2743.2012.00453.x

Kamprath, E. J., \& Watson, M. E. (1980). Conventional soil and tissue tests for assessing the phosphorus status of soils. American Society of Agronomy., Madison, Wiscosin.

Lipson, D. A., Bowman, D. W., \& Monson, R. K. (1996). Luxury uptake and storage of nitrogen in the Rhizomatous Alpine herb, Bistorta bistortoides. Ecology, 37, 1227-1285. http://dx.doi.org/10.2307/2265597

Lopez-Bellido, L., Lopez-Bellido, R., \& Redondo, R. (2005). Nitrogen efficiency in wheat under rainfed Mediterranean conditions as affected by split nitrogen application. Field Crops Research, 94, 86-97. http://dx.doi.org/10.1016/j.fcr.2004.11.004

Mohd, H. I., Jaafar, H. Z. E., Rahmat, S., \& Rahman, Z. A. (2010). The relationship between phenolics and flavonoids production with total non structuctural carbohydrate and photosynthetic rate in Labisia pumila Benth. under high $\mathrm{CO}_{2}$ and nitrogen fertilization. Molecules, 16, 162-174. http://dx.doi.org/10.3390/molecules 16010162

Murphy, J., \& Riley, J. P. (1962). A modified single solution method for the determination of phosphate in natural waters. Analytica Chimica Acta, 27, 31-36. http://dx.doi.org/10.1016/S0003-2670(00)88444-5 
Ohno, T., \& Grunes, D. L. (1985). Potassium-Magnesium Interactions Affecting nutrient uptake by Wheat forage. Soil Science Society of America Journal, $485-690$. http://dx.doi.org/10.2136/sssaj1985.03615995004900030032x

Raun, W. R., \& Johnson, G. V. (1999). Improving Nitrogen Use Efficiency for Cereal Production. Journal of Plant Nutrition, 91, 357-363. http://dx.doi.org/10.2134/agronj1999.00021962009100030001x

Rice, C. W., \& Havlin, J. L. (1994). Intergrating Mineralizable Nitrogen Indices into fertilizer Nitrogen Recommendations. Soil Testing: Prospects for Improving Nutrient Recommendations: Soil Science Society of America Special Publication, 40, 1-13.

Romheld, V., \& Kirkby, E. A. (2010). Research on potassium in agriculture: needs and prospects. Plant and Soil, 335, 155-180. http://dx.doi.org/10.1007/s11104-010-0520-1

Sharpley, A. N. (1994). Innovative Soil Phosphorus Availability Indices: Assessing Inorganic Phosphorus. Soil Testing: Prospects for Improving Nutrient Recommendations: Soil Science Society of America Special Publication, 40, 115-142.

Sparks, D. L. (1987). Potassium dynamics in soils. Advances in Soil Science, 6, 1-63. http://dx.doi.org/10.1007/978-1-4612-4682-4_1

Sparks, D. L., Feigenbaum, S., \& Bar-Tal, A. (1990). Dynamics of soil potassium in multicationic systems. Potash Institute, Bern.

Stanford, G., \& Smith, S. J. (1972). Nitrogen Mineral Potential of soils. Soil Science Society of America Journal, 36, 465-472. http://dx.doi.org/10.2136/sssaj1972.03615995003600030029x

van den Berg, A. K., \& Perkins, T. D. (2004). Evaluation of a portable chlorophyll meter to estimate chlorophyll and nitrogen contents in sugar maple (Acer saccharum Marsh.) leaves. Forest Ecology and Management, 200, 113-117. http://dx.doi.org/10.1016/j.foreco.2004.06.005

Vitosh, M. L., Johnson, J. W., \& Mengel, D. B. (1995). Tri-State Fertilizer Reccomendations for Corn, Soybean, Wheat and Alfalfa. Extension Bulletin, E-2567.

Waring, S. A., \& Bremmer, J. M. (1964). Ammonium production in soil under waterlogged conditions as an index of nitrogen availability. Nature, 201, 951-952. http://dx.doi.org/10.1038/201951a0

Welte, E., \& Werner, W. (1963). Potassium-magnesium antagonism in soils and crops. Journal of the Science of Food and Agriculture, 14, 186-197. http://dx.doi.org/10.1002/jsfa.2740140309

\section{Copyrights}

Copyright for this article is retained by the author(s), with first publication rights granted to the journal.

This is an open-access article distributed under the terms and conditions of the Creative Commons Attribution license (http://creativecommons.org/licenses/by/3.0/). 